\title{
Biological Parameters of Blacksaddled Coralgrouper (Plectropomus laevis Lacepède, 1801) Eggs and Larvae
}

\author{
Regina Melianawati ${ }^{\star}$ and Bejo Slamet \\ Institute for Mariculture Research and Fisheries Extension, \\ Banjar Dinas Gondol, Ds. Penyabangan, Kec. Gerokgak, Buleleng 81155, Bali, Indonesia \\ *Email: regina.melnawati@yahoo.com
}

\begin{abstract}
Blacksaddled coralgrouper, Plectropomus laevis, is an endangered species of marine fish. As part of conserving their existence in the wild, culture of this species has been started. However, knowledge of biological parameters of this species as important indicators to observe the fish growth in mariculture scale, is limited. The purpose of this study was to observe biological parameters during eggs, larval to juvenile stage of blacksaddled coralgrouper in mariculture hatchery. The eggs were obtained from natural spawning of domesticated broodstocks. Larvae rearing was done in hatchery at three different times as replicates. Larval were fed with zooplankton which consist of rotifers Brachionus sp., wild copepods and Artemia. Artificial feed was also given to the fish larvae. Larval samples were taken one Day After Hatching (DAH), then continued every 5 days started at 5 to $45 \mathrm{DAH}$ by using five larvae each sampling time. The observed parameters were diameter of eggs and oil globule, total length and standard length of larvae length of dorsal and pelvic fin spines of larvae. Furthermore, growth pattern of those length parameters was analysed by regression equation. The result showed that diameter of blacksaddled coralgrouper eggs was $835.19 \pm 15.29 \mu \mathrm{m}$, while oil globule was $177.78 \pm 10.30 \mu \mathrm{m}$. The growth patterns of larval total length and standard length were exponential, while dorsal and pelvic fin spines were polynomial. The length of time from larvae to achieve juvenile stage was range between 45-50 days. All of these information can be used as references either in larvae rearing or for further study of the fish.
\end{abstract}

Keywords: blacksaddled coralgrouper, larval development, endagered, growth

\section{Introduction}

The blacksaddled coralgrouper (Plectropomus laevis) is one of marine finfishes which is distributed in Indo-Pacific waters (Heemstra and Randall, 1993). This fish has a high economic value since they can be traded as ornamental fish in juveniles and as consumption fish on either high prices and high level of demand (Bebeja, 2014; Frisch et al., 2016). However, the status of this fish in the wild is classified as vulnerable (IUCN, 2012). Therefore, mariculture of this fish in a scale of cultivation hatchery is necessary to maintain their sustainability in nature.

The mariculture activities for blacksaddled coralgrouper fish has been carried out in Institute for Mariculture Research since 2010 (Slamet et al., 2010). Their juveniles could be produced successfully for the first time in the world (Slamet, 2012; Syafputri, 2012). Availability of eggs is one of key factors for successful hatchery, so the quality of eggs should be considered. The good eggs are fertile, round shaped, transparent and floating in the water (Suwirya et al., 2006).
Larval is a very important stage in hatchery activities. The success of larvae to be juveniles is a success indicator of hatcheries works. One of the important aspects during larval development is larval growth. The growth can be defined as a change of larvae size achieved in a certain period compared to size at the beginning of that period (Effendie, 1997). The parameters commonly used to evaluate the fish growth, mainly in larval stage, are total length and standard length (Fishbase, 2019). Blacksaddled coralgrouper larvae also has a specific characteristic that is the presence of dorsal and pelvic fin spines appear to grow elongated and then will shorten, as in other kinds of groupers belongs to Serranidae family (Fukuhara and Fushimi, 1988). Therefore, the size of those both fin spines could be used as an indicator of growth for blacksaddled coralgrouper larvae.

The purpose of this study was to determine the performance of blacksaddled coralgrouper ( $P$. laevis) eggs derived from natural spawning of domesticated broodstocks, performance of the several biological parameters on larval growth and the growth pattern of blacksaddled coralgrouper from larvae to juvenile stage. 


\section{Materials and Methods}

The eggs were collected and put them into fiberglass tank (500 L). Only the fertile eggs were selected and hatched in larval rearing tanks (4,000L). Each tanks were equipped with aerator system to supply dissolved oxygen and under natural lighting. Phytoplankton Nannochloropsis oculata was added to larval rearing tanks in the morning started on 2 Days After Hatching (DAH). Zooplankton rotifers Brachionus rotundiformis were given as initial exogenous feed to larval on 2 DAH evening and continued with wild copepods on $3 \mathrm{DAH}$, while the other one, Artemia naupli were given later on 20$25 \mathrm{DAH}$. Micro diets also added as artificial feed for larval started on $10 \mathrm{DAH}$ according to the best result from Slamet et al. (2015).

Parameters of eggs observed were diameter and oil globule. Ninety eggs from three different batch of spawning were used as samples. Measurement of eggs was done using micrometer in stereoscopic microscope. Diameter of eggs and oil globules measured as straight line through the midpoint of the circle from one side to the other as straight line (Figure 1.). Larval development was described by using measurements of total length and standard length according to Glamuzina et al. (1998). The others larval development, which is a typical biological characteristic for groupers, were dorsal and pelvic fin spines were measured according to Colin and Koenig (1996).

Larval samples were taken from 1, 5, 10, 15, $20,25,30,35,40 \mathrm{DAH}$. The number of larval were five individuals from each sampling times. Larval samples were taken randomly and placed them on single concave object glass. Larval were keep alive during measurement process. Measurement was done by using stereoscopic microscope Olympus $\mathrm{SZH}$ was already equipped by micrometer.

Data obtained from observations of eggs are presented as graphical data. Data of larval parameters are displayed as mean values \pm deviation standard and illustrated as a graphical form. The larval growth pattern was then analyzed by using an excel program with regression and correlation equations. Analysis of all data, both on eggs and larval, was performed descriptively.

\section{Results and Discussion}

The diameter of blacksaddled coral grouper eggs used in this study was 835.00 $15.29 \mu \mathrm{m}$ (Figure 2.). The smallest diameter size was 816.67 $\mu \mathrm{m}$, whereas the largest diameter was $883.33 \mu \mathrm{m}$. However, most of eggs were $833.33 \mu \mathrm{m}$ in diameter. Each eggs used in this study had an oil globule with a diameter of $177 \pm 87 \mu \mathrm{m}$ (Figure 3.). The smallest diameter of oil globule was $166.67 \mu \mathrm{m}$; on the other hand, the largest was $200.00 \mu \mathrm{m}$. The diameter of oil globule was $183.33 \mu \mathrm{m}$ mostly.

The average size of the fish eggs diameter used in this study was bigger than was reported by Slamet et al. (2010) that ranged from 750 to 840 $\mu \mathrm{m}$ or $805 \mu \mathrm{m}$ in average. However, it was almost similar to the research conducted by Melianawati et al. (2012a) that was ranged $800-850 \mu \mathrm{m}$. The diameter of this eggs is almost similar to the diameter of egg from others fishes, such as coral trout Plectropomus leopardus that was ranged 800$850 \mu \mathrm{m}$ (Suwirya et al., 2006), humpback grouper Cromileptes altivelis 800-900 $\mu \mathrm{m}$ (Sugama et al., 2001) and dusky grouper Epinephelus marginatus was varying from 738 to $940 \mu \mathrm{m}$ (Glamuzina et al., 1998). Thus, the diameter of the blacksaddled coralgrouper eggs is almost the same as the other diameter sizes of grouper eggs. It is important to observe the eggs diameter because it will influence to larval body size, even larval survival (Gisbert et al., 2000). The egg diameter itself depends on several factors including water temperature. Okumura (2003) mentioned that eggs in natural temperature conditions 20 up to $27^{\circ} \mathrm{C}$ have a larger diameter than those at lower temperatures.

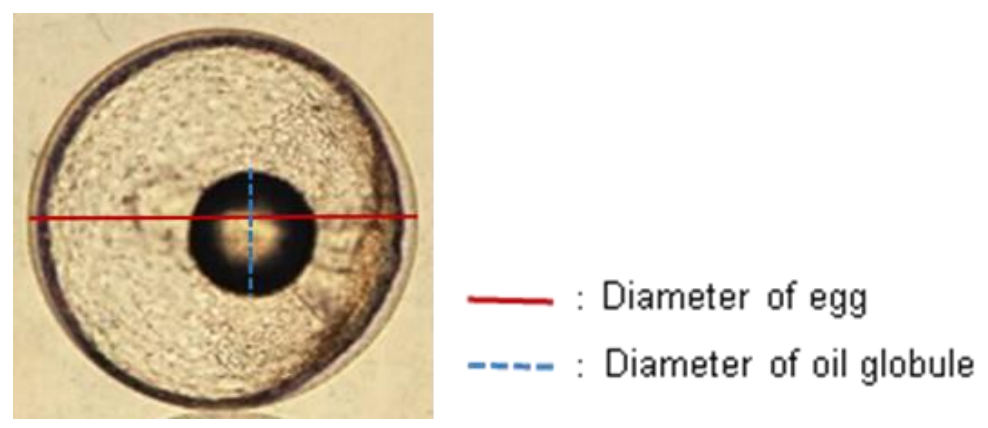

Figure 1. Measurement diameter of egg and oil globule 


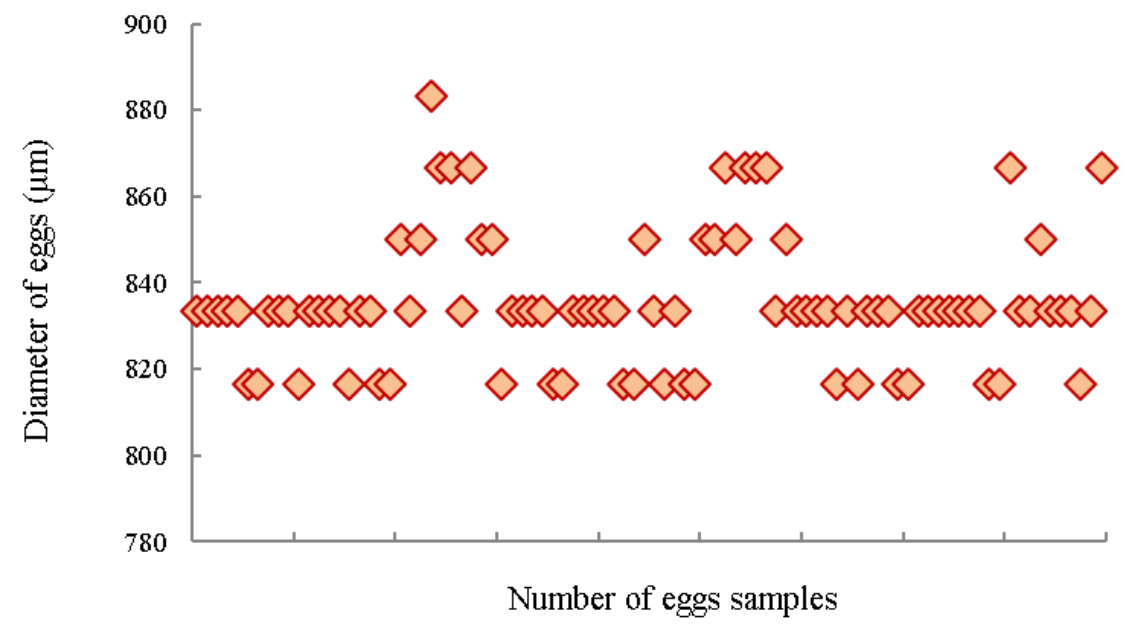

Figure 2. Eggs diameter of blacksaddled coralgrouper (Plectropomus laevis)

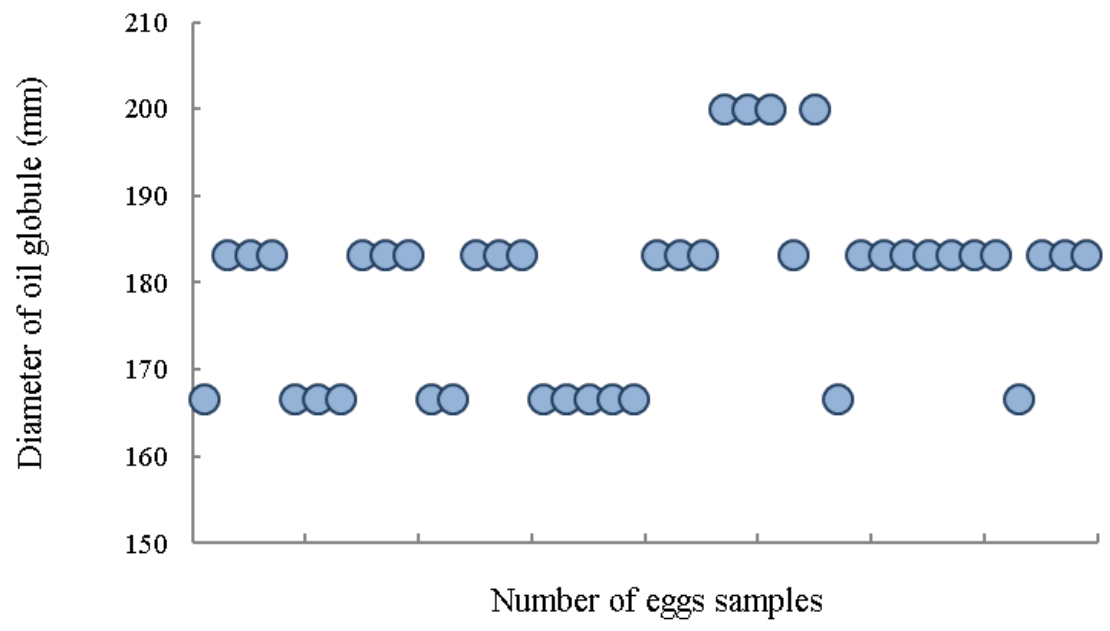

Figure 3. Oil globule diameter of blacksaddled coralgrouper (Plectropomus laevis)

The eggs of blacksaddled coralgrouper have oil globule as one of endogenous feed or endogenous energy for newly hatched larvae. Each egg generally has one round shaped of oil globule. The results of the diameter measurement of oil globule in this study almost the same result as those reported by Slamet et al. (2010), which are 160-185 $\mu \mathrm{m}$ with an average of $175 \mu \mathrm{m}$, but it slightly smaller than those used in the study by Melianawati et al. (2012a), which are about 168-200 $\mu \mathrm{m}$. This difference in size occurred because of the eggs used in the two studies obtained from different spawner broodstocks, also different spawning time and condition. When compared with other groupers species, those size of oil globule is almost the same as the diameter oil globule of coral trout $P$. leopardus which ranges from 179 to $180 \mu \mathrm{m}$ (Melianawati et al., 2012b). The blacksaddled coralgrouper eggs used in this study have an oil globule diameter in a range that is almost the same as that used in previous studies and with other groupers.

Oil globule is one of the endogenous energy at the time of hatching (Kohno et al., 1986). The oil globule is not related to larval growth directly but it commonly used for larval movement activities (Imanto et al., 2003). One of the larval movement is swimming to search the live feeds. Larvae that have larger oil globule means that they have more energy sources. It means those larvae have wider swimming abilities in searching for exogenous feed. The success of larvae to consumed live feed during the transition from endogenous to exogenous energy will influence subsequent larval survival (Moteki et al., 2001). 


\section{Larvae}

Blacksaddled coralgrouper larvae on 1 DAH had a total length of $2.49 \pm 0.11 \mathrm{~mm}$ (Figure 4.). Larval total length increased as they getting older. It was indicated by the very close correlation between the total length and age of larval $(r=0.99)$. The results of this study also showed that the total length of larvae increased exponentially until the larvae achieved to juvenile stage that occurred on $40 \mathrm{DAH}$. Started from 1 to $40 \mathrm{DAH}$, larval total length increased about $16.84 \mathrm{~mm}$ with daily growth rate was $5.16 \pm 0.38 \%$ and growth coefficient was $2.07 \pm 0.15$.

Larvae on $1 \mathrm{DAH}$ had $2.34 \pm 0.08 \mathrm{~mm}$ standard length (Figure 5.). Larval total length increased as the age of larva increased. It was indicated by the close correlation between total length and age of the larvae $(r=0.99)$. Similar as total length, larval standard length also increased exponentially until the larvae reached the juvenile stage on $40 \mathrm{DAH}$. The results also showed that larval standard length increased $13.84 \mathrm{~mm}$ with daily growth rate was $4.82 \pm 0.39 \%$ and growth coefficient was $1.93 \pm 0.16$.

The larval standard length also had a very close linear correlation $(r=1)$ with its total length (Figure 6.). In larvae with a total length of 2-4 $\mathrm{mm}$, it appeared that the standard length was also in the range of 2-4 $\mathrm{mm}$. In those sizes, the larval size tended to equal between total length and standard length. However, when the larvae have reached total length of more than $5 \mathrm{~mm}$, it appeared that the standard length tended to be lower than the total length. Larval standard length also varied with larval total length. The further analysis exhibited that the standard length was $86.21 \pm 6.37 \%$ of larval total length.

Larval fin spines, both on dorsal and pelvic, began to be detected on10 $\mathrm{DAH}$. Those larval fin spines usually began to grow on 6-7 DAH. However, because of the sampling time in this study was performed in every 5 days, that was on 5 and 10 $\mathrm{DAH}$, so that the fin spines have not grown yet on 5 $\mathrm{DAH}$ and it started to be detected on $10 \mathrm{DAH}$. Those larval dorsal fin spines were the second dorsal spines as according to Kohno et al. (1993).

The results showed that the growth of larval dorsal spines had a strong correlation in polynomials $(r=0.99)$ to the larval age (Figure 7.). Dorsal fin spines of larvae in length $0.66 \pm 0.41 \mathrm{~mm}$ began to be detected on $10 \mathrm{DAH}$, then their growth increased to reach the longest length of $6.43 \pm 1.27 \mathrm{~mm}$ on 30 DAH larvae. After that, it reduced to be $5.27 \pm 0,49$ $\mathrm{mm}$ on $40 \mathrm{DAH}$.

The dorsal fin spines also had close correlation with larval total length $(r=0.97)$ in polynomial (Figure 8). The figure showed that the larval dorsal fin spines began to grow on larvae in 3$4 \mathrm{~mm}$ total length. The dorsal fin spines increased in length until they reached a certain total length, which is in the range of $15 \mathrm{~mm}$ as the longest size in this study. Furthermore, the size decreased as the increased of larval total length.

The growth of larval pelvic fin spines has a similar pattern to that of dorsal fin spines (Figure 9.). Pelvic fin spines had a polynomial growth pattern and it had also close correlation $(r=0.99)$ with increasing of larval age. The figure also showed that the growth of pelvic fin spines reached its largest size on $30 \mathrm{DAH}$ larvae and after that, the pelvic fin spines reduced.

The larval pelvic fin spines were also had closely correlation ( $r=0.96)$ with increasing of larval total length in polynomial (Figure 10.). Similar to the dorsal fin spines, larval pelvic fin spines began to grow on larvae of 3-4 $\mathrm{mm}$ in total length, reached their longest size on about $15 \mathrm{~mm}$ total length and after that, they reduced with the increasing of larval total length.

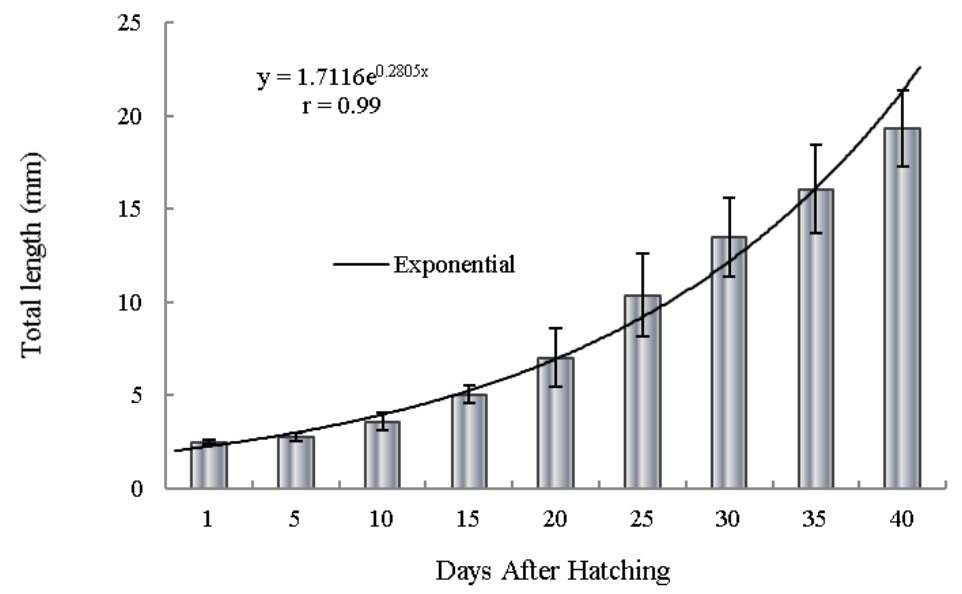

Figure 4. Total length of Blacksaddled coralgrouper, (Plectropomus laevis) larvae 


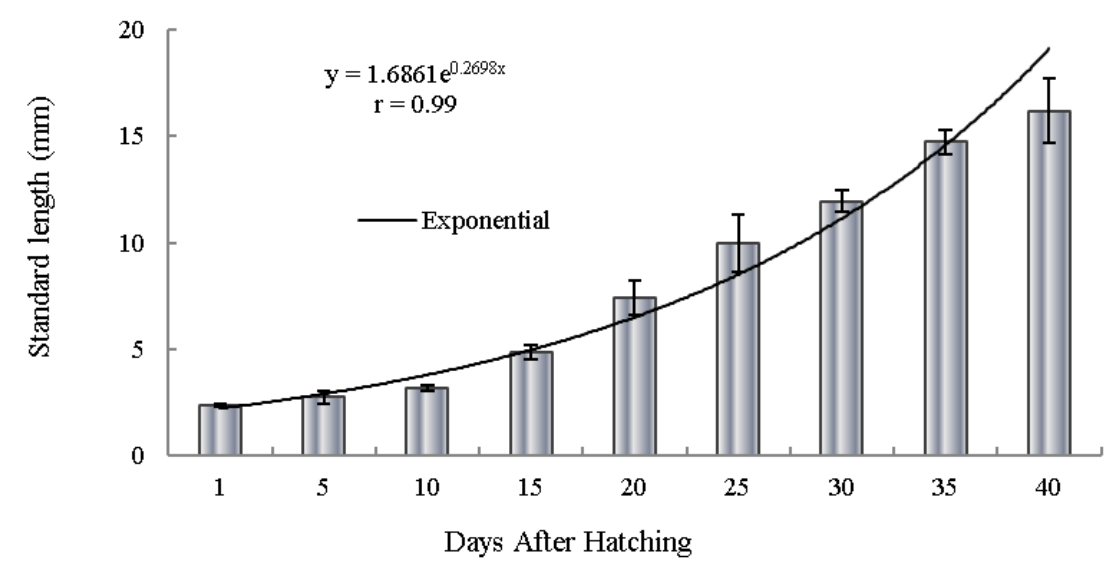

Figure 5. Standard length of Blacksaddled coralgrouper, (Plectropomus laevis) larvae

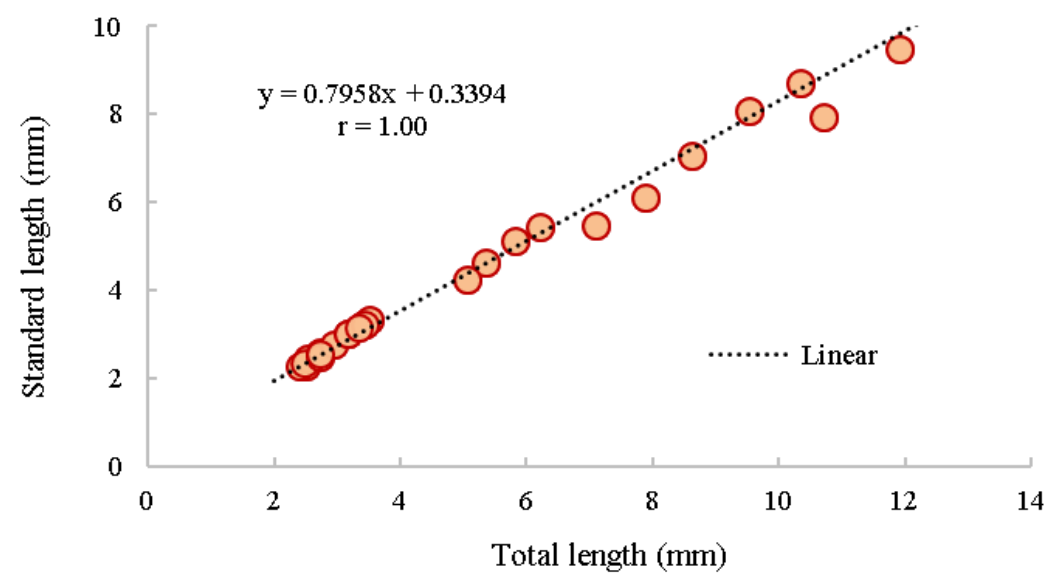

Figure 6. Standard length-total length relationship of blacksaddled coralgrouper, (Plectropomus laevis) larvae

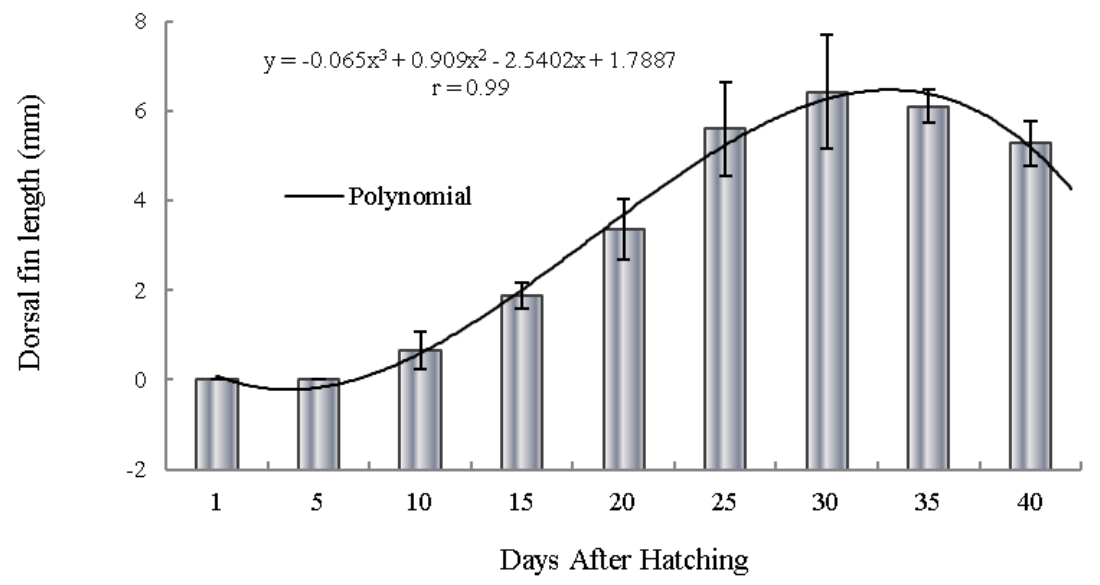

Figure 7. Dorsal fin length of blacksaddled coralgrouper, (Plectropomus laevis) larvae

The development of $P$. laevis from larvae to juvenile stages was indicated by some changes in their body (Figure 11.). The newly hatched larvae had big yolk sac and an oil globule as their source endogenous feed (Figure 11a.). Larvae on $1 \mathrm{DAH}$ had a very simple body shape, still used their 
endogenous as their source of feed, the mouth had not opened yet, the eyes had not been pigmented and the digestive tract had not been formed (Figure 11b.). The mouth of 5 DAH larvae had already opened, the eye has already undergone pigmentation and a simple digestive tract has been formed (Figure 11c.). This showed that that time, larvae had already caught on the available zooplankton in their rearing water as the live feeds and used them as exogenous feed because their endogenous feeds had already completely absorbed. Larval fin spine, both dorsal and pelvic, had already grown on $10 \mathrm{DAH}$ (Figure 11d.). The larval fin spines continued to grow elongated and the development of the digestive system became more complex on 20 DAH (Figure 11e.) and 30 DAH (Figure 11f.). Larvae had rapid growth on $40 \mathrm{DAH}$, length of the fin spines had more reduced and their body resembled that of young fish (Figure 11g.). Those indicated that larvae already reached metamorphosis stage. When larvae completely metamorphosis to be juvenile, blacksaddled coralgrouper juvenile has different body shape than the larvae stage and has distinctive yellow and black color on their dorsal (Figure 11h.).

The biological parameters commonly used to evaluate the larval growth are the length of the larval body, both total length and standard length. Result of this study, the growth of total length and standard length of blacksaddled coralgrouper larvae increases exponentially with the increasing age of larvae. Developmental of larval fin spines are also used to evaluate the larval growth for groupers. The growth of the larval 's body length is followed by the growth of fin spines, both on dorsal and pelvic. The growth pattern of larval fin spines in this study are slightly different from those in the previous study. Those growth patterns in this study were polynomial, whereas in the previous study they were linear (Melianawati et al., 2012a). This is because of

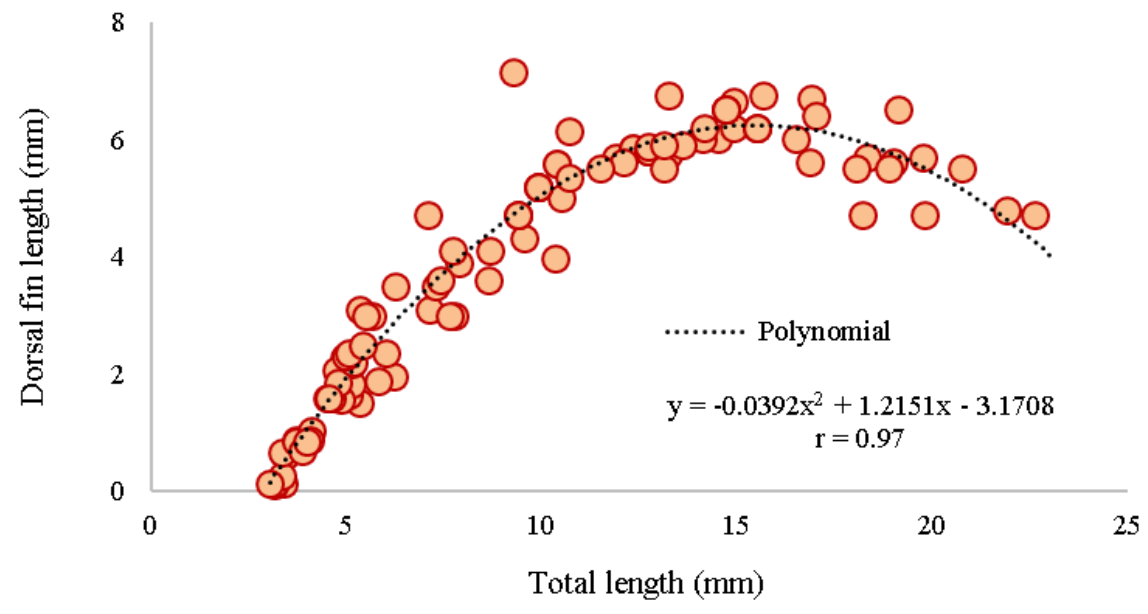

Figure 8. Dorsal fin-total length relationship of blacksaddled coralgrouper, (Plectropomus laevis)

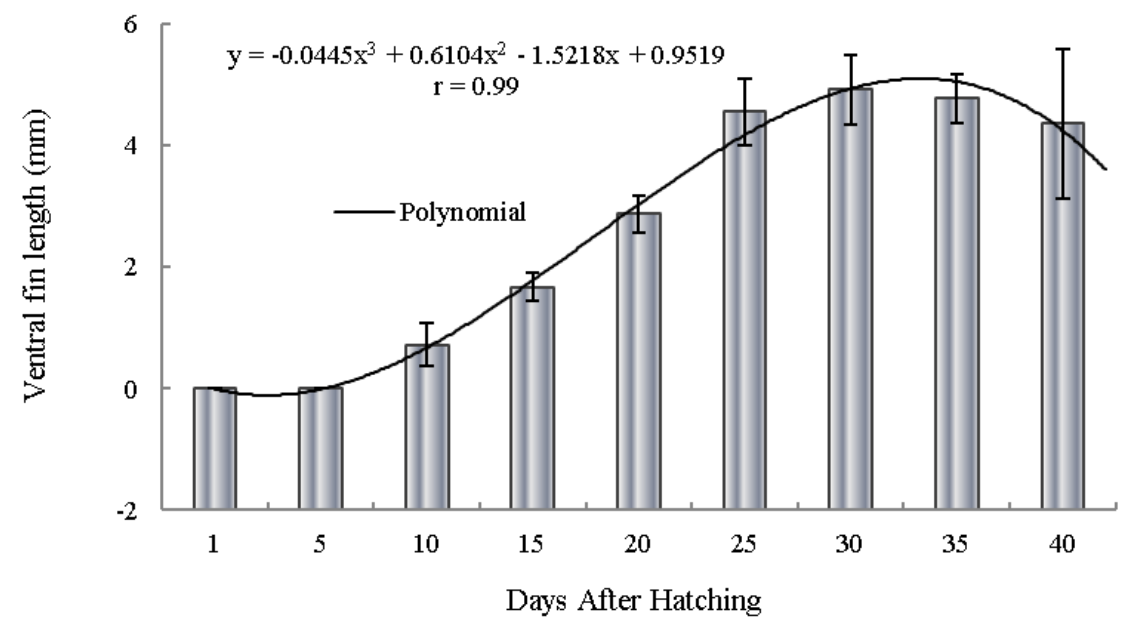

Figure 9. Ventral fin length of Blacksaddled coralgrouper larvae, (Plectropomus laevis) 
the larvae in this study seem to grow faster than those in previous study. For comparison, in the previous study, until the end of the study on $45 \mathrm{DAH}$, the growth of fin spines has still not reached maximum size, so that it still in linear growth and had not reduced yet. In contrast, in this study, the fin spines have already reached a maximum length on
$30 \mathrm{DAH}$ larvae and after that the length of fin spines started to reduce up to $40 \mathrm{DAH}$ larvae. The growth pattern of larval fin spines from family Serranidae is growing elongated and then will shorten or reduce (Fukuhara and Fushimi, 1988). The growth of larval fin spines in this study has the same pattern as other kinds of grouper species such as Epinephelus

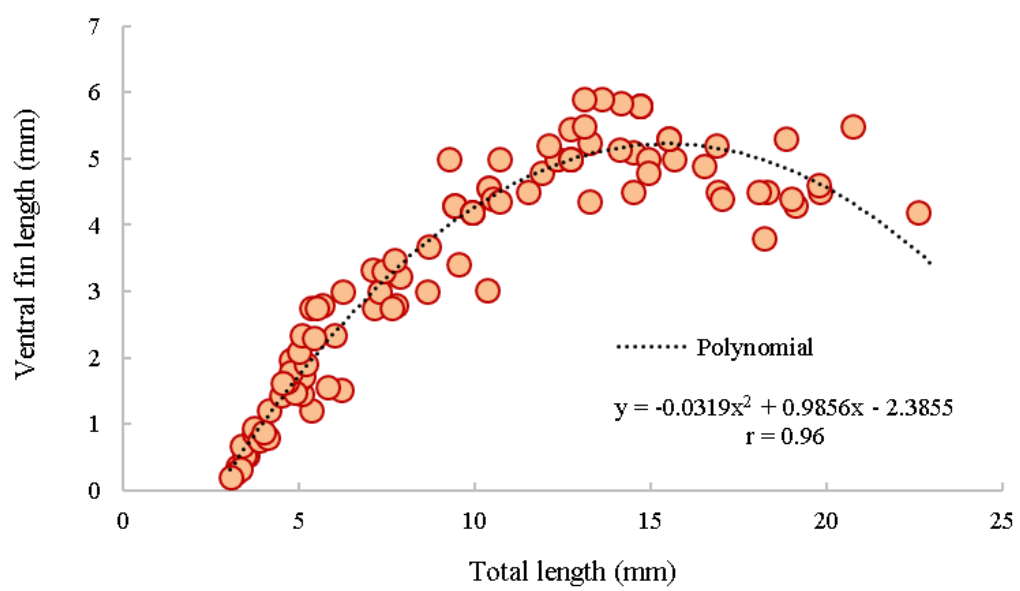

Figure 10. Ventral fin-total length relationship of blacksaddled coralgrouper, (Plectropomus laevis)

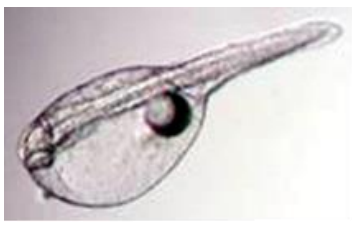

a

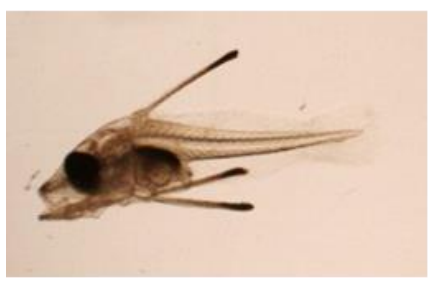

d

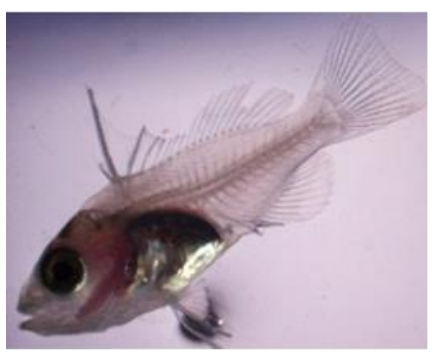

g

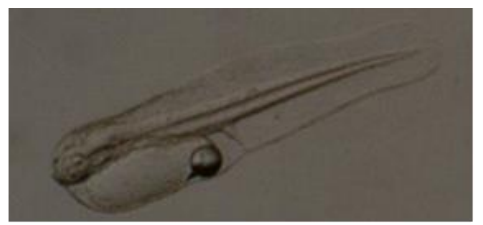

$\mathrm{b}$

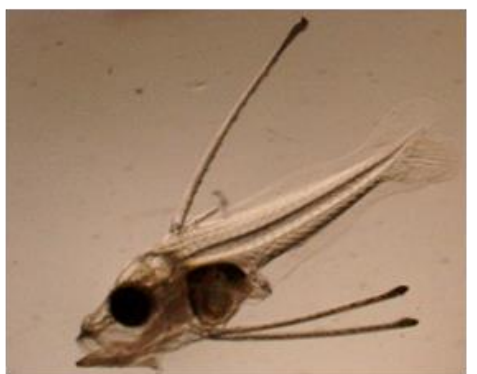

e

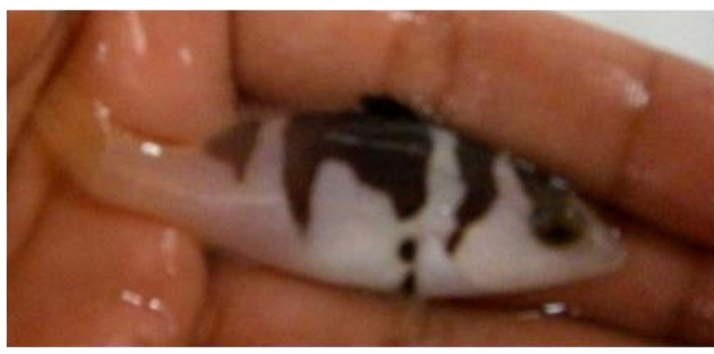

h

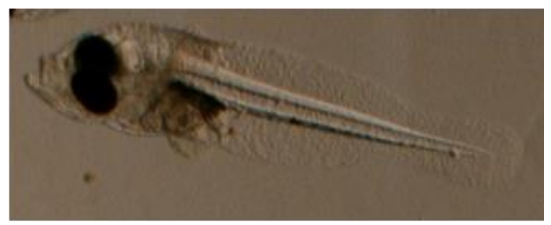

$\mathrm{c}$

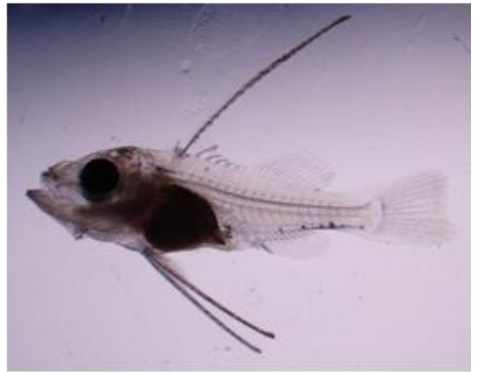

f

Figure 11. Developmental larval growth of blaclsaddled coralgrouper, (Plectropomus laevis). (a) Newly hatched larvae, (b) 1 DAH, (c) 5 DAH, (d) $10 \mathrm{DAH}$, (e) $20 \mathrm{DAH},(\mathrm{f}) 30 \mathrm{DAH}$, (g) $40 \mathrm{DAH}$ and (h) juvenile. 
fuscoguttatus (Kohno et al., 1993), malabar grouper E. malabaricus (Leu et al., 2005) and dusky grouper E. marginatus (Cunha et al., 2013). Thus, larval growth in this study, based on the growth of their fin spines, was faster than in previous studies.

Some factors that can be the cause of differences in larval growth, such as quality of eggs, environmental conditions during larval rearing and feed given to larvae. In this study, copepods are another kind of zooplankton, besides rotifers, that also used as live feed for feeding larvae. In previous study, only rotifers used as live feed and did not use copepods. Copepods in this study obtained from the wild, collected from pond waters. Copepods contain useful nutrients for the growth of marine fish larvae (Van der Meeren et al., 2008).

Larvae begin to undergo metamorphosis on $40 \mathrm{DAH}$ to be juveniles. These changes are characterized by changes body shape that is totally different from larval performance. Larvae reach juveniles stage at the age of 48-50 DAH for larvae rearing in hatchery (Slamet et al., 2011). Blacksaddled coralgrouper has a distinctive body colors are black and yellow on its dorsal, which distinguishes it from other kinds of Serranide (Nair et al., 2013).

Research on the growth of blacksaddled coralgrouper (Plectropomus laevis), mainly in the larval stage that was produced from hatchery activities, is not widely available yet. Based on our experiences, mariculture of fish from genus Plectropomus tends to be more difficult than other grouper species, since biological data in the larval stage are limited. Therefore, the biological information obtained in this study are expected as basic data and reference for future research. Larvae rearing of this species is an alternative to fulfill the market demands to this highly economical fish, in addition it also to keep the sustainability of this species in the wild.

\section{Conclusion}

The eggs of blacksaddled coralgrouper (Plectropomus laevis), were 835.19 $\pm 15.29 \mu \mathrm{m}$ in diameter and each egg had oil globule which was $177.78 \pm 10.30 \mu \mathrm{m}$ in diameter. The growth rate of larval total length was $5.16 \pm 0.38 \%$, while the standard length was $4.82 \pm 0.39 \%$. Larval standard length was in line with larval total length. The growth of dorsal fin spines and pelvic fin spines was polynomial correlation in the growth of total length. The growth patterns of larval total length and the standard length are exponential, whereas the growth of dorsal fin spines and pelvic fin spines are polynomial.

\section{References}

Bebeja. 2014. Kerapu raja sunu: kecil hias, besar konsumsi. Available at http://www.bebeja. com. Accessed 16 March 162019.

Colin, P.L. \& Koenig, C.C., 1996. Spines in larval red grouper, Epinephelus morio: Development and function. Proceedings of the $44^{\text {th }}$ Gulf and Caribbean Fisheries Institute, 31-38 pp.

Cunha, M.E., Re, P., Quental-Ferreira, H., Gavaia, P.J., \& Pous ${ }^{\sim}$ ao-Ferreira, P., 2013. Larval and juvenile development of dusky grouper Epinephelus marginatus reared in mesocosms. J. Fish Biol., 83: 448-465. doi:10.1111/jfb.12180

Effendie, M.I., 1997. Biologi perikanan. Yayasan Pustaka Nusatama. Yogyakarta. 163 p.

Fishbase. 2019. Plectropomus laevis. Available at http://www.fishbase.org. Accessed 14 March 2019.

Frisch, A.J., Cameron, D.S., Pratchett, M.S., Williamson, D.H., Williams, A.J., Reynolds, A.D., Hoey, A.S., Rizzari, J.R., Evans, L., Kerrigan, B., Muldoon, G., Welch, D.J., Hobbs, J-P.A., 2016. Key aspects of the biology, fisheries and management of coral grouper. Rev. Fish. Biol. Fisheries., $\quad$ 26(3): 303-325 doi:10.1007/s11160-016-9427-0

Fukuhara, O. \& Fushimi, T., 1988. Fin differentiation and squamation of artificial reared grouper Epinephelus akaara. Aquaculture, 69: 379386. doi:10.1016/0044-8486(88)90344-4

Gisbert, E., Williot, P., Castello-Orvay, F., 2000. Influence of egg size on growth and survival of early stages of Siberian sturgeon (Acipenser baeri) under small scale hatchery conditions. Aquaculture, 183: 83-94. doi:10. 1016/S00448486(99)00287-2

Glamuzina, B., Skaramuca, B., Glavić, N., Kožul, V., Dulčić, J., \& Kraljević, M., 1998. Egg and early larval development of laboratory reared dusky grouper, Epinephelus marginatus (Lowe, 1834) (Picies, Serranidae). Sci. Mar., 62(4): 373-378. doi: 10.3989/scimar.199 8.62n4373

Heemstra, P.C. \& Randall, J.E. 1993. Plectropomus laevis. in: FAO Species Catalogue 16. Rome. 290-292 pp.

Imanto, P. T., Melianawati, R., \& Slamet, B., 2003. Pola penyerapan nutrisi endogen dan perkembangan morfologis pada stadia awal 
larva ikan napoleon (Cheilinus undulatus). J. Penelitian Perikanan Indonesia, 9(2): 9-14.

IUCN., 2012. Plectropomus laevis. Available at http://www.iucnredlist.org. Accessed 31 May 2013.

Kohno, H., Hara, S \& Taki, Y., 1986. Early larval development of the seabass Lates calcarifer with emphasis on the transition of energy sources. Bull. Jap. Soc. Sci. Fisheries, 52 (10): 1719-1725.

Kohno, H., S. Diani, S., \& Supriatna, A., 1993. Morphological development of larval and juvenile grouper, Epinephelus fuscoguttatus. Japan. J. Ichthyol., 40(3): 307-316.

Leu, M-Y., Liou, C-H., \& Fang, L-S., 2005. Embryonic and larval development of the malabar grouper, Epinephelus malabaricus (Pisces: Serranidae). J. Mar. Biol. Ass. U.K. 85: 1249-1254.

Moteki, M. Yoseda, K., Sahin, T., Üstündağ, C., \& H. Kohno, H., 2001. Transition from endogenous to exogenous nutritional sources in larval Black Sea turbot Psetta maxima. Fisheries Sci., 67: 571-578. doi:10.1046/j.14442906.2001.00292.x

Melianawati, R., Astuti, N.W.W., Slamet, B., 2012a. Pola pertumbuhan larva ikan kerapu raja sunu (Plectropoma laevis Lacepède, 1801) dan tingkat konsumsinya terhadap zooplankton rotifer (Brachionus rotundiformis). J. IImu Teknol. Kel. Tropis, 4: 217-228. doi:10.29244/jitkt.v4i2.778 4

Melianawati, R., N.W.W. Astuti, K. Suwirya., 2012b. Produksi benih kerapu sunu Plectropomus leopardus di Balai Besar Penelitian dan Pengembangan Budidaya Laut. Prosiding Indoaqaua-Forum Inovasi Teknologi Akuakultur. 139-148 pp.

Nair, R. J., Kumar, S. D., Paul, S., \& Kuriakose, S., 2013. Occurrence of two serranid fish from Indian waters with a note on their taxonomy. Mar. Biodiversity Record 6(e41): 1-4. doi:10.1017/S1755267213000171

Okumura, S., 2003. Variation in egg size spawned under different water temperatures in the red spotted grouper, Epinephelus akaara. Suisanzoshoku 51(2): 231-232. doi:10.112 33/aquaculturesci1953.51.231

Slamet, B., \& Tridjoko, 1997. Pengamatan pemijahan alami, perkembangan embrio dan larva ikan kerapu batik, Epinephelus microdon dalam bak terkontrol. J. Penelitian Perikanan Indonesia III (4): 40-50. doi:10.15578/ jppi.3.4.1997.40-50

Slamet, B., Suwirya, K., Setiadi, I., Melianawati, R., \& Andamari, R., 2010. Observation on natural spawning of blacksaddled coralgrouper (Plectropoma laevis) in captivity, in: Sudaryanto, A. \& Febriani, M. (Eds.), Proceedings of the International Conference of Aquaculture Indonesia and International Conference on Shrimp Aquaculture. Indonesian Aquaculture Society. Surabaya, Indonesia, October 26-30, 1116-1120 pp.

Slamet, B., Suwirya, K., Melianawati, R., Ismi, S., Andamari, R., $2011 . \quad$ Pengamatan perkembangan morfologi, penyerapan energi endogenous, dan isi perut larva ikan kerapu raja sunu (Plectropoma laevis). Pros. Forum Inovasi Teknol. Akuakultur, 2: 1217-1223.

Slamet, B., 2012. Pelopor pembenihan ikan kerapu raja sunu. TrobosAqua, 4(I): 36-37.

Slamet, B., T. Aslianti, K.M. Setiawati, W. Andriyanto \& A. Nasukha., 2015. Pemeliharaan larva kerapu raja sunu (Plectropomus laevis) dengan perbedaan awal pemberian pakan buatan. $J$. Riset Akuakultur, 10(4):531-540. doi:10.15578/jra.10.4.2015.531-540

Sugama, K., Tridjoko, Slamet, B., Ismi, S., Setiadi, E., \& Kawahara, S., 2001. Petunjuk teknis produksi benih ikan kerapu bebek, Cromileptes altivelis. Balai Riset Perikanan Laut Gondol. 14$16 \mathrm{pp}$.

Suwirya, K., Prijono, A. Hanafi, A., Andamari, R., Melianawati, R., Marzuqi, M., Sugama, K., Giri, N.A., 2006. Pedoman teknis pembenihan ikan kerapu sunu (Plectropomus leopardus). Pusat Riset Perikanan Budidaya. 18 p.

Syafputri, E., 2012. Indonesia kembangkan benih kerapu rajasunu. Available at http://www.antaranews.com. Accessed 28 July 2012.

Van der Meeren, T., Olsen, R.E., Hamre, K. \& Fyhn, H.J., 2008. Biochemical composition of copepods for evaluation of feed quality in production of juvenile marine fish. Aquaculture, 274: 375-397. doi:10.1016/ j.aquaculture.2007.11.041 